\title{
Geographical and temporal differences in the urinary excretion of inorganic arsenic: a Belgian population study
}

\author{
J P Buchet, J Staessen, H Roels, R Lauwerys, R Fagard
}

\begin{abstract}
Objective-This Belgian study assessed the geographical and temporal differences in the exposure of the population to inorganic arsenic, a known carcinogen. Methods-In the CadmiBel study (1985-9) the $24 \mathrm{~h}$ urinary arsenic excretion was measured, as an index of recent exposure, in industrialised cities (Liège: $n=664$, Charleroi: $n=291$ ), in a rural control area (Hechtel-Eksel: $\mathbf{n}=397$ ), and in rural districts in which the population had possibly been exposed through the drinking water or the emissions of nonferrous smelters (Wezel: $n=93$, Lommel: $n=111$, and Pelt: $n=133)$. In the PheeCad study, in 1991-5, the rural areas $(n=609)$ were re-examined together with an urban control area (Leuven: $\mathbf{n}=152$ ).
\end{abstract}

Results-The CadmiBel results showed that after adjustment for sex, age, and body mass index, the $24 \mathrm{~h}$ arsenic excretion was on average low in Liège (91 nmol), Charleroi (155 nmol), HechtelEksel (144 nmol), and Wezel (158 nmol), whereas the highest excretions were found in Lommel (570 nmol) and Pelt (373 nmol). During the PheeCad study, the mean $24 \mathrm{~h}$ arsenic excretion in the rural areas ranged from 81 to $111 \mathrm{nmol}$. This was lower than six years earlier and similar to the excretion in the control town (108 nmol). Longitudinal studies in 529 people living in the rural areas confirmed that their $24 \mathrm{~h}$ arsenic excretion had decreased $(P<0.001)$ from 222 to 100 nmol. As well as the drinking water, industry was likely to be a source of the increased exposure in Lommel and Pelt in 1985-9, because at that time the urinary arsenic excretion did not follow the regional differences in the arsenic content of the drinking water, because the fall in the arsenic excretion over time coincided with the implementation by industry of stricter environmental regulations, because in individual subjects the urinary arsenic excretion was inversely correlated with the distance to the nearest smelter, and because an increased arsenic excretion was only found downwind from the main smelter. The official network that monitors the arsenic concentration in airborne and fall out dust did not detect the high exposure in Lommel and Pelt between 1985 and 1989.

Conclusion-This study highlights the necessity to validate environmental monitoring programmes by directly estimating the internal exposure of the population.

(Occup Environ Med 1996;53:320-327)

Keywords: arsenic absorption; environmental pollution; general population

Arsenic is an ubiquitous element. Its toxicity mainly results from excessive exposure to inorganic derivatives, in particular those in which arsenic is in the trivalent state, such as $\mathrm{As}_{2} \mathrm{O}_{3}$. The general population is exposed to inorganic arsenic through inhalation of dust particles containing arsenic and through ingestion of foodstuffs and tap or bottled water containing arsenic pumped from geological layers containing arsenic, and possibly through smoking. ${ }^{1}$ The relative importance of these sources may vary depending on the area of residence and lifestyle habits.

Long term oral exposure of the general population to inorganic arsenic through drinking water may affect various organs such as the skin, the liver, the heart, the peripheral vascular system, the central and peripheral nervous system, and the bone marrow. Similar effects have been reported in subjects who have regularly consumed medications containing arsenic, mainly Fowler's solution. ${ }^{2}$ However, the main risk after long term ingestion of inorganic arsenic is the induction of cancer of the skin and possibly also of various internal organs. ${ }^{3}$ In workers chronically exposed to inorganic arsenic by inhalation mortality from lung cancer increases. ${ }^{4}$

Non-ferrous smelters have been an important source of emission of various inorganic substances (lead, cadmium, zinc, arsenic) in the environment mainly in the past when regulations on industrial emissions were less stringent. Between 1985 and 1989 we examined a random sample of the adult population living near non-ferrous smelters in Belgium (Noorderkempen) and have found that their lifetime integrated exposure to cadmium (assessed by measuring cadmium in urine) was significantly increased compared with subjects living in areas less polluted by cadmium (CadmiBel study). ${ }^{5}$ Because non-ferrous smelters may release not only cadmium but also arsenic we analysed urine samples for their combined content of inorganic arsenic $\left(A s_{i}\right)$ and its methylated metabolites monomethylarsonic acid (MMA) and dimethylarsinic acid (DMA). The sum of 
these three arsenic species represents a reliable indicator of recent uptake of inorganic arsenic. ${ }^{6}$ Inhabitants of the Noorderkempen and the corresponding control rural area (Hechtel-Eksel) were re-examined five years later (Pheecad study between 1991 and 1995). During this second survey an additional group of control subjects were examined in an urban area (Leuven).

\section{Materials and methods \\ STUDY POPULATIONS \\ CadmiBel study (1985-9)}

A detailed protocol of the CadmiBel study has already been published. ${ }^{7}$ A random sample of 2327 men and women aged between 20 and 80 was recruited in four areas of Belgium: two urban (Charleroi and Liège) and two rural (Hechtel-Eksel and Noorderkempen) districts. Both rural areas are 10 to $15 \mathrm{~km}$ apart but in one of them (Noorderkempen) two non-ferrous smelters were active at the time of the survey and a third one, dismantled in 1974, was still surrounded by industrial waste deposits (fig 1).

From 1985 to 1989 a total of 2327 subjects with a minimum age of 20 and who had lived for at least eight years in the areas were studied. The participation rate among the subjects contacted was $78 \%$ in the two rural areas ( $n=$ $1103)$ and $39 \%$ in the two urban areas $(n=$ 1220). Among the 2327 subjects, 214 were excluded because not all relevant measurements could be obtained, 44 were excluded because their 24 hour urine sample was judged to be under or over collected on the basis of previously published criteria, ${ }^{8} 343$ (313 men and 30 women) because they had possibly been exposed at work, 36 because they were not within the age boundaries from 20 to 79 years, and one subject living in the Liège area, because her questionnaire showed that at the time of the examination she was taking medications containing arsenic. In this woman the urinary arsenic excretion was $34 \mu \mathrm{mol} / 24 \mathrm{~h}$. Thus, for the present analysis the CadmiBel study group totalled 1689 subjects.

\section{PheeCad study (1991-5)}

The 1103 CadmiBel participants living in the rural districts were invited to take part in a longitudinal survey, the PheeCad (Public Health and Environmental Exposure to Cadmium) study. ${ }^{9}$ This study took place between 1991 and 1995. Eighty two subjects had died. After excluding those who were severely ill $(n=4)$ or had moved $(n=7)$, 1010 people were left. Of these, $821(8 \%)$ participated. For the present analysis, 30 subjects were excluded because not all relevant measurements had been obtained, eight were excluded because their 24 hour urine sample was under or over collected, ${ }^{8} 171$ because they had potentially been exposed to heavy metals at work, and three subjects because their questionnaire showed that they had been on medications containing arsenic. In these subjects the urinary arsenic excretion was 192,68 , and $39 \mu \mathrm{mol} / 24 \mathrm{~h}$. For the present analysis the PheeCad study group thus totaled 609 subjects. In $529(87 \%)$ of these subjects the urinary arsenic excretion had been measured both at baseline (CadmiBel study) and during follow up (PheeCad study).

During the PheeCad study an additional group including 135 volunteers, mainly recruited among hospital staff, and 25 patients with essential hypertension from the out patient clinic of the University Hospital in Leuven were also examined. ${ }^{10}$ These subjects were included in the present analysis because
Figure 1 The investigated areas in Belgium (insert) and detailed description of the rural area.

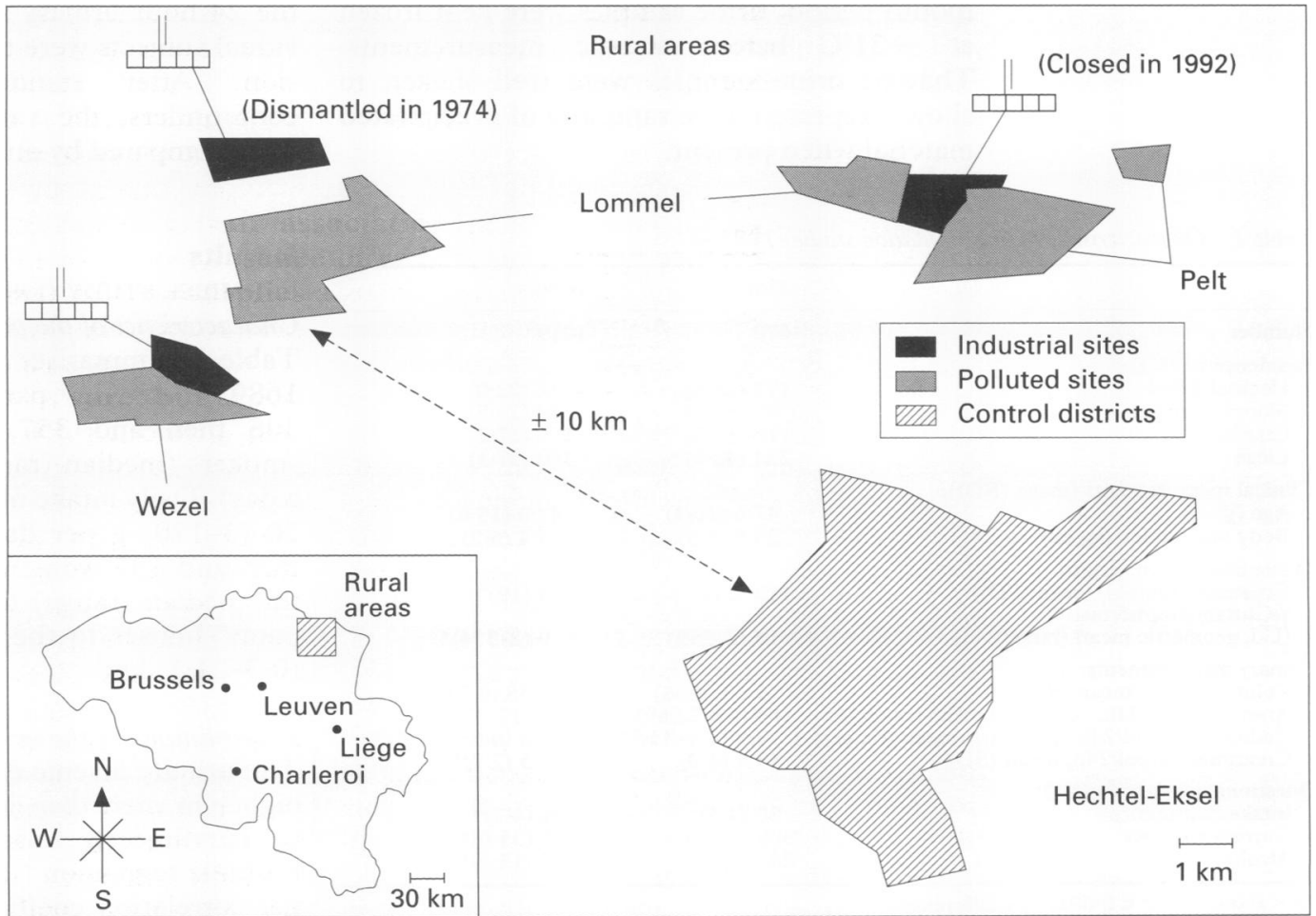


they lived in an area of Belgium where no smelters had been in operation, and because they constituted a contemporary urban control group for the PheeCad study. Timed urine specimens for the measurement of arsenic were available in 152 subjects.

\section{EPIDEMIOLOGICAL METHODS}

The CadmiBel and PheeCad studies were conducted with the use of similar epidemiological techniques. ${ }^{7}$ All subjects were repeatedly visited at home. During each survey the subjects completed the same self administered questionnaire inquiring into their medical history, current and past occupations, smoking habit, consumption of alcohol, and intake of medications. In the rural area social class was determined from each person's current and past occupations, ${ }^{11}$ according to the rules of the Office of Population Censuses and Surveys in London. ${ }^{12}$

In the two rural areas the geographical position of the subjects' homes as well as of the industrial settlements was determined from maps drawn at a scale of $1 / 10000$. The distance of each house from the nearest smelter was then calculated.

The CadmiBel and PheeCad participants collected a 24 hour urine sample for the measurement of arsenic, cadmium, and creatinine in a wide necked polyethylene container. A venous blood sample was obtained within two weeks after urine collection. The serum creatinine concentration was measured as an index of renal function and the serum $\gamma$ glutamyltransferase activity as a measure of alcohol consumption. ${ }^{13}$

\section{BIOCHEMICAL MEASUREMENTS}

The urinary cadmium ${ }^{7}$ and arsenic $^{14}$ concentrations were measured by atomic absorption spectrometry. Samples collected during both surveys were analysed for arsenic within a six month period; urine samples were kept frozen at $-21^{\circ} \mathrm{C}$ before arsenic measurements. Thawed urine samples were well shaken to allow a representative sampling of precipitated material when present.
Urinary arsenic was measured after arsine generation under conditions which allow the measurement of the sum of inorganic arsenic and its methylated metabolites (monomethylarsonic acid (MMA) and dimethylarsinic acid (DMA)) without notable interference of seafood trimethylated arsenicals. ${ }^{14}$ A possible but limited influence of fish consumption on the urinary excretion of $\mathrm{DMA}^{15}$ cannot totally be excluded; however, the large number of subjects examined, the low rate of fish consumption among Belgians, and the geographical vicinity and similar social classes of the populations under study strongly reduced the probability that differences in urinary excretion of arsenic were caused by differences in seafood ingestion.

During the study, the laboratory participated in the external quality control programme organised by the Centre de Toxicologie du Québec, Laval University, Québec, Canada. In 18 analyses the mean (SD) results were $0.4 \%$ (4\%) lower than the target values indicating that no changes in the analytical procedure occurred during the measurement period.

The creatinine concentration in serum and urine $^{16}$ and the activity of $\gamma$-glutamyltransferase ${ }^{17}$ in serum were measured by automated enzymatic techniques (Technicon Autoanalyzer, Technicon Instruments, Tarrytown, New York, USA).

\section{STATISTICAL ANALYSIS}

Data base management and statistical analyses were performed with the SAS software (The SAS Institute, Cary, North Carolina). Nonnormally distributed variables (arsenic in urine) were logarithmically transformed and, unless otherwise specified, described by the geometric mean and the extremes.

Means were compared by Student's $t$ test and proportions by a $\chi^{2}$ statistic. Covariates of the 24 hour urinary arsenic excretion in individual subjects were traced by stepwise regression. After standardisation for known confounders, the various geographical areas were compared by analysis of covariance.

\section{Results}

\section{CADMIBEL STUDY (1985-9)}

Characteristics of the population

Table 1 summarises the characteristics of the 1689 CadmiBel participants among whom 308 men and 357 women were currently smokers (median (range) 18 (1-75) cigarettes a day). Daily intake of alcohol (median (range) 20 (3-170) g per day) was reported by 245 men and 137 women. In the two rural areas, the median (range) distance from the participants' houses to the nearest smelter was 3.0 $(0 \cdot 3-21 \cdot 1) \mathrm{km}$.

\section{Determinants of the urinary arsenic excretion}

The urinary arsenic excretion was consistently higher in men than in women and tended to be curvilinearly related to age. In stepwise multiple regression (table 2), the multiple partial correlation coefficients for the linear and 
Table 2 Correlates of the urinary excretion of arsenic (logarithmically transformed) in the CadmiBel study (1985-9) as identified by stepwise multiple regression

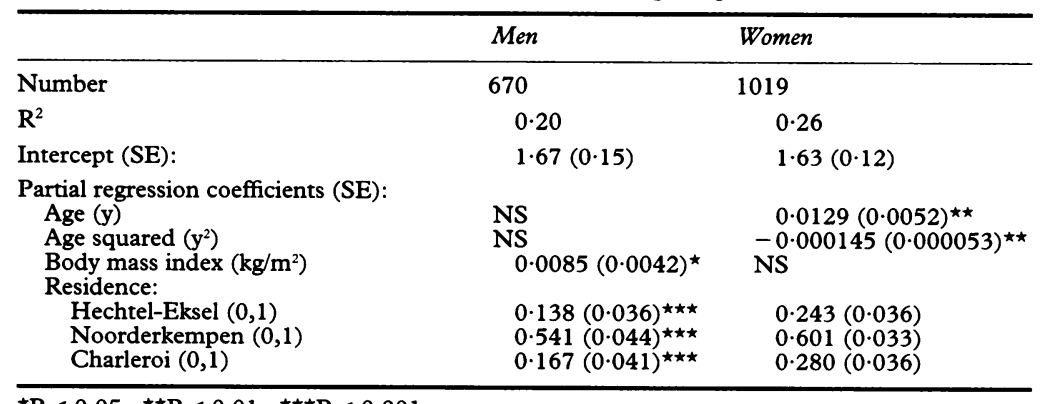

${ }^{\star} \mathrm{P}<0.05 ;{ }^{\star \star} \mathrm{P}<0.01 ;{ }^{\star \star \star} \mathrm{P}<0.001$.

The four areas in the analysis (Hechtel-Eksel, Noorderkempen, Charleroi, and Liège) were identified by three dummy variables.

The variables which were considered, but did not enter the regression model $(P>0 \cdot 15)$ were: social class, $\log \gamma$-glutamyltransferase, intake of diuretics, current smoking, and serum creatinine concentration.

Table 3 Correlates of log urinary arsenic excretion in the CadmiBel and PheeCad participants who resided in the rural areas with low and high exposure

\begin{tabular}{lll}
\hline & $\begin{array}{l}\text { CadmiBel study } \\
(1985-9)\end{array}$ & $\begin{array}{l}\text { PheeCad study } \\
(1991-5)\end{array}$ \\
\hline Number & 734 & 609 \\
$\mathrm{R}^{2}$ & 0.31 & 0.02 \\
Intercept (SE) & $2 \cdot 00(0 \cdot 13)$ & $2 \cdot 13(0.06)$ \\
Partial regression coefficients (SE): & & \\
$\quad$ Sex (1 = men, 2 = women) & $-0.087(0.029)^{\star \star \star}$ & $-0.077(0.033)^{\star}$ \\
$\quad$ Age (y) & $+0.0155(0.0055)^{\star \star}$ & $\mathrm{NS}$ \\
$\quad$ Age squared (y $)$ & $-0.000178(0 \cdot 000055)^{\star \star \star}$ & $\mathrm{NS}$ \\
$\quad$ Intake of diuretics $(0,1)$ & $0.114(0.051)^{\star}$ & $\mathrm{NS}$ \\
$\quad$ Residence: & $\mathrm{NS}$ & $-0.104(0.046)^{\star \star}$ \\
$\quad$ Wezel $(0,1)$ & $0.587(0.039)^{\star \star \star}$ & $\mathrm{NS}$ \\
$\quad$ Pelt $(0,1)$ & $0.413(0.036)^{\star \star \star}$ & $\mathrm{NS}$ \\
\hline
\end{tabular}

${ }^{\star} \mathrm{P}<0.05 ;{ }^{\star \star} \mathrm{P}<0.01 ;{ }^{\star \star \star} \mathrm{P}<0.001$.

The four areas in the analysis (Hechtel-Eksel, Wezel, Lommel, and Pelt) were identified by three dummy variables. The covariates which were considered, but did not enter the regression model $(\mathrm{P}>0 \cdot 15)$ were: body mass index, social class, log $\gamma$-glutamyltransferase as index of alcohol consumption, current smoking, and renal function as measured by the serum creatinine concentration. squared terms of age combined were 0.07 ( $P$ $=0.10)$ in men and $0.08(P=0.01)$ in women. Overall, the urinary arsenic excretion went through a maximum at 30 years in men and 40 years in women. The partial regression coefficients showed that, after adjustement for all other covariates in the model including sex, aging from the fourth to the seventh decade of life was associated with a decrease in the urinary arsenic excretion averaging $19 \%$ in men and $16 \%$ in women. In men, the urinary arsenic excretion was also positively correlated with body mass index (partial correlation coefficient: $0.07 ; P=0.02$ ). After adjustment for age and body mass index, the area of residence appeared as a strong determinant of the urinary arsenic output. The multiple partial correlation coefficients for the three dummy variables combined, which identified the four areas in the analysis (Hechtel-Eksel, Noorderkempen, Liège, and Charleroi), were 0.44 $(P<0.001)$ in men and $0.50(P<0.001)$ in women (table 2 ). The variables which did not enter the model $(P>0.15)$ were: social class, current smoking, the intake of diuretics, renal function as measured by the serum creatinine concentration, and alcohol intake assessed by the activity of serum $\gamma$-glutamyltransferase. The urinary excretion of arsenic adjusted for the significant covariates amounted to 91 , 155,144 , and $341 \mathrm{nmol} / 24$ hours in the Liège, Charleroi, Hechtel-Eksel, and Noorderkempen areas, respectively. In the Noorderkempen (Wezel, Pelt, and Lommel) the excretion was significantly lower in Wezel than in Pelt and Lommel (fig 2). (Conversion of units: arsenic, $1 \mu \mathrm{mol}=74.9 \mu \mathrm{g}$; cadmium, $1 \mathrm{nmol}=112.4 \mathrm{ng} ; \quad$ creatinine, $1 \mathrm{mmol}=$ $112 \cdot 13 \mathrm{mg}$.)
Figure 2 The geometric mean (SE) urinary excretion of arsenic adjusted for sex, age linear and squared terms), and body mass index in different areas examined during the CadmiBel (1985-9) and PheeCad (1991-5) studies.

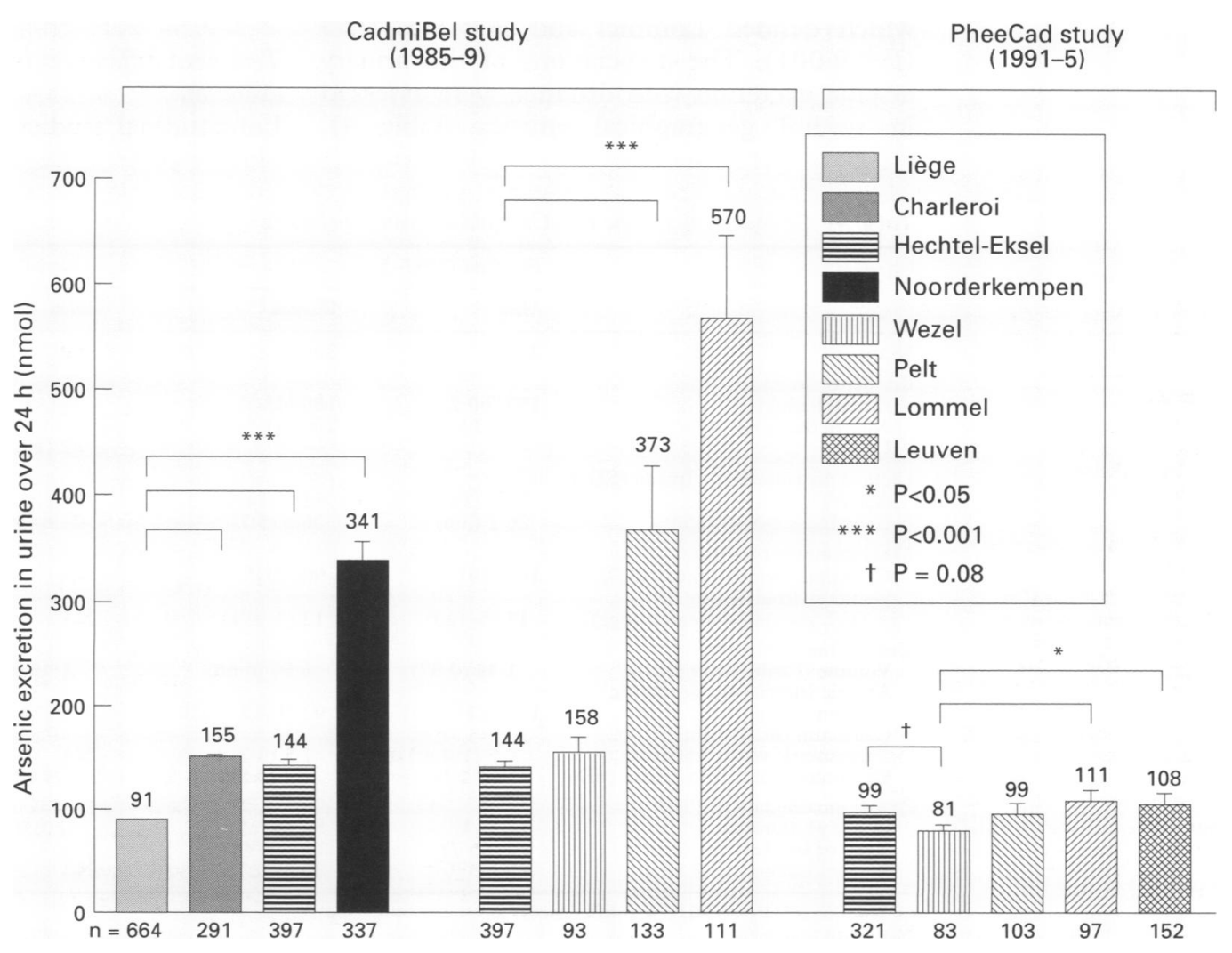


Table 4 Distance from the nearest smelter as a determinant of log urinary arsenic excretion in the rural areas surveyed 1985-9

\begin{tabular}{lllllll}
\hline & \multicolumn{3}{c}{ Regression } & & \multicolumn{2}{l}{ Partial regression } \\
Residence & $n$ & coefficient & Pvalue & & coefficient & P value \\
\hline Hechtel-Eksel & 397 & -0.0220 & $>0.05$ & & -0.0116 & $>0.05$ \\
Wezel & 93 & 0.0919 & $>0.05$ & & 0.0916 & $>0.05$ \\
Lommel & 111 & -0.1054 & $<0.01$ & & -0.1180 & $<0.01$ \\
Pelt & 133 & -0.0229 & $<0.01$ & & -0.0222 & $<0.02$ \\
\hline
\end{tabular}

^Adjusted for relevant covariates (see table 3 )

Distance to the nearest smelter was measured in $\mathrm{km}$.

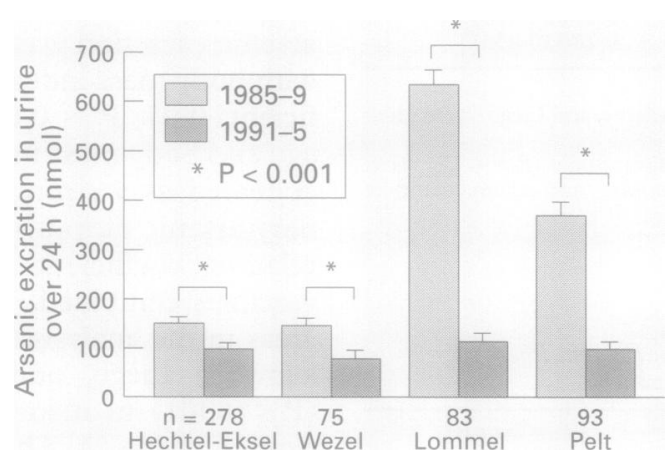

Figure 3 The geometric mean (SE) urinary excretion of arsenic adjusted for sex, age (linear and squared terms), and body mass index in subjects examined twice during the CadmiBel (1985-9) and PheeCad (1991-5) studies.

Further analyses were performed in the CadmiBel participants, who lived in the rural areas (table 3). Men and women were pooled in these analyses, because the determinants of the urinary arsenic excretion were largely the same in the two sexes (table 2). The four districts in the analyses (Hechtel-Eksel, Wezel, Lommel, and Pelt; fig 1) were coded by three dummy variables. Again, the geographical position was a strong determinant of the urinary arsenic excretion. The multiple partial correlation coefficient for the dummy variables which defined Lommel and Pelt was 0.53 $(P<0.001)$. The associations of the urinary arsenic excretion with distance were assessed in several geographical entities (table 4).
These analyses showed that distance was not correlated with the urinary arsenic excretion in the rural control area (Hechtel-Eksel) and in Wezel both before and after adjustment for the relevant covariates listed in table 3. However, both in Lommel and Pelt, the distance to the nearest smelter remained independently correlated with the urinary arsenic excretion after similar adjustments (table 4).

\section{PHEECAD STUDY (1991-5)}

Characteristics of the population

Table 5 shows the characteristics of the several groups examined between 1991 and 1995 In the PheeCad group, the median distance from the participants' houses to the nearest smelter was $7 \cdot 8(0 \cdot 3-16 \cdot 2) \mathrm{km}$.

Determinants of the urinary arsenic excretion At follow up, in the PheeCad survey, the relation between the urinary arsenic excretion and age was weak and failed to reach the $5 \%$ threshold of significance. When men and women were pooled, the main determinant of the urinary arsenic excretion was residence. Living in Wezel was associated with a significantly lower urinary arsenic excretion than was living in Hechtel-Eksel, Lommel, and Pelt. The partial correlation coefficient associated with living in Wezel was $0.11(P<0.01)$, and with sex was $0.09(P=0.02)$.

Both before and after adjustement for sex, age (linear and squared terms), and body mass index, the urinary arsenic excretion in the rural areas was considerably lower (fig 2) during the PheeCad study than six years earlier and did not differ from the excretion found in the urban Leuven area, where non-ferrous smelters had never been in operation. In Wezel, the urinary arsenic excretion tended to be lower than in the three other areas (fig 2).

Temporal differences in the urinary arsenic excretion

Longitudinal studies of the urinary excretion

Table 5 Characteristics of the PheeCad and Leuven populations

\begin{tabular}{|c|c|c|c|c|}
\hline & \multicolumn{2}{|l|}{ PheeCad (1991-5) } & \multicolumn{2}{|c|}{ Leuven (1992-3) } \\
\hline & Men & Women & Men & Women \\
\hline Number & 221 & 388 & 82 & 70 \\
\hline $\begin{array}{l}\text { Residence (n (\%)): } \\
\text { Hechtel-Eksel } \\
\text { Noorderkempen } \\
\text { Leuven }\end{array}$ & $\begin{array}{r}133(60 \cdot 2) \\
88(39 \cdot 8) \\
-\end{array}$ & $\begin{array}{l}188(48 \cdot 5) \\
200(51 \cdot 5) \\
-\end{array}$ & $\overline{\bar{z}}(100 \cdot 0)$ & $\overline{\overline{70}}(100 \cdot 0)$ \\
\hline $\begin{array}{l}\text { Clinical measurements (mean (SD)): } \\
\text { Age }(\mathrm{y}) \\
\text { Body mass index }\left(\mathrm{kg} / \mathrm{m}^{2}\right)\end{array}$ & $\begin{array}{l}50 \cdot 1(14 \cdot 9) \\
26 \cdot 1(3 \cdot 6)\end{array}$ & $\begin{array}{l}51 \cdot 0(14.4) \\
26.4(5 \cdot 7)\end{array}$ & $\begin{array}{l}33 \cdot 6(10 \cdot 1) \\
24 \cdot 6(3 \cdot 5)\end{array}$ & $\begin{array}{l}32 \cdot 5(10 \cdot 4) \\
21 \cdot 8(3 \cdot 4)\end{array}$ \\
\hline $\begin{array}{l}\text { Measurements on serum: } \\
\text { Creatinine }(\mu \mathrm{mol} / \mathrm{l} \text {, mean (SD)) } \\
\gamma \text {-glutamyltransferase } \\
\text { (U/l, geometric mean (range)) }\end{array}$ & $109(19)$ & $90(21)^{\star}$ & NA & NA \\
\hline $\begin{array}{l}\text { Urinary measurements: } \\
\text { Volume }(1 / 24 \mathrm{~h}, \text { mean }(\mathrm{SD})) \\
\text { Arsenic (nmol/24h, geometric } \\
\text { mean (range)) }\end{array}$ & $1.49(0.57)$ & $1.59(0.66)$ & $1.46(0.68)$ & $1.64(0.63)$ \\
\hline $\begin{array}{l}\text { Cadmium (nmol/24h, } \\
\text { geometric mean (range)) } \\
\text { Creatinine (nmol/24h, mean (SD)) }\end{array}$ & $\begin{array}{l}7 \cdot 5(1 \cdot 4-60 \cdot 0) \\
15 \cdot 4(4 \cdot 2)\end{array}$ & $\begin{array}{l}7 \cdot 5(6 \cdot 7-46 \cdot 5) \\
9 \cdot 9(2 \cdot 2)^{\star}\end{array}$ & $\begin{array}{l}\text { NA } \\
15 \cdot 9(2 \cdot 6)\end{array}$ & $\begin{array}{l}79(3-1066)^{\pi \pi \pi} \\
\text { NA } \\
10 \cdot 9(1 \cdot 7)^{\star}\end{array}$ \\
\hline $\begin{array}{l}\text { Questionnaire data }(\mathrm{n}(\%)) \text { : } \\
\text { Intake of diuretics } \\
\text { Current smokers } \\
\text { Alcohol intake }\end{array}$ & $\begin{array}{l}12(5 \cdot 4) \\
79(35 \cdot 7) \\
73(33 \cdot 0)\end{array}$ & $\begin{array}{r}59(9 \cdot 7)^{\star} \\
112(28 \cdot 9) \\
28(7 \cdot 2)^{\star}\end{array}$ & $\begin{array}{l}0(0 \cdot 0) \\
\text { NA } \\
\text { NA }\end{array}$ & $\begin{array}{l}0(0 \cdot 0) \\
\text { NA } \\
\text { NA }\end{array}$ \\
\hline
\end{tabular}

${ }^{\star} \mathrm{P}<0.05 ; \star \star \star \star \mathrm{P}<0.001 ;$ sex differences.

$\mathrm{NA}=$ not analysed. 
of arsenic were available in 529 PheeCad participants. In all these subjects the urinary arsenic excretion decreased $(P<0.001)$ from 222 (range 13-11718) $\mathrm{nmol} / 24 \mathrm{~h}$ to 100 (1-17882) nmol/24 h. Moreover, in each community there was a significant $(P<0.001)$ drop in the urinary output of arsenic (fig 3 ).

\section{Discussion}

Inorganic arsenic can easily enter the organism by inhalation or ingestion. Once absorbed it is rapidly methylated to monomethyl and mainly dimethylarsenic derivatives which are excreted in urine as MMA and DMA. More than half of the inhaled or ingested dose is eliminated in urine within a few days; the methylated metabolites constitute up to $80 \%$ of the excreted arsenic, ${ }^{18}$ but a fraction of the absorbed inorganic arsenic is always excreted unchanged. ${ }^{19}$ For practical purposes, the sum of $\mathrm{As}_{\mathrm{i}}, \mathrm{MMA}$, and DMA in urine can be considered as an indicator of recent exposure (either by inhalation or by ingestion) to inorganic arsenic. ${ }^{20}$ In subjects non-occupationally exposed to arsenic and living in areas not environmentally contaminated by inorganic arsenic the amount excreted in urine $\left(\mathrm{As}_{\mathrm{i}}+\right.$ $\mathrm{MMA}+\mathrm{DMA}$ ) is usually below $200 \mathrm{nmol} / 24 \mathrm{~h}$ (15 $\mu \mathrm{g} /$ day).$^{6}$

During the CadmiBel study (1985-9), the mean daily urinary excretion of arsenic adjusted for sex, age, and body mass index, ranged from 91 to $155 \mathrm{nmol} / 24 \mathrm{~h} \mathrm{(6.8}$ to 11.6 $\mu \mathrm{g} / 24 \mathrm{~h})$ in Liège, Charleroi, and HechtelEksel. This agrees well with the result of a duplicate meal study $(n=122)$ that we had previously carried out in three areas of Belgium (Brussels, Charleroi, and Liège); the mean oral daily intake of arsenic amounted to $160 \mathrm{nmol} / 24 \mathrm{~h}(12 \mu \mathrm{g} / 24 \mathrm{~h}) .^{21}$

In the CadmiBel study the mean urinary excretion of arsenic was significantly lower in Liège than in Hechtel-Eksel and in Charleroi. This may be due to the fact that the rural control area (Hechtel-Eksel) is only 10 to $15 \mathrm{~km}$ from where non-ferrous smelters were active (Noorderkempen), whereas in the Charleroi area, steel furnaces probably emitted fly ash containing arsenic.

The present study clearly showed that before 1991 men and women living in the Noorderkempen, where non-ferrous smelters had been active since the beginning of this century, inhaled and ingested an amount of inorganic arsenic about twice as high as in the other areas. Several arguments support the hypothesis that environmental contamination due to emissions of arsenic by the smelters may have contributed to the higher exposure to arsenic in the Noorderkempen.

(1) The highest urinary excretion of arsenic was found in the subjects living in the Lommel and Pelt areas. The environmental pollution by cadmium in the Noorderkempen is well known and concomitant contamination by other non-ferrous elements ( $\mathrm{Zn}, \mathrm{Pb}, \mathrm{As}$, etc) has been found. ${ }^{722-25}$ Increased concentrations of arsenic ( $>20 \mathrm{ppm}$ ) have been found in some kitchen gardens in Lommel and Pelt, especially near the old zinc smelter in the Lommel area, which was dismantled in 1974. ${ }^{22}$

(2) During the CadmiBel study there was a significant inverse association between urinary arsenic excretion and the distance from the nearest smelter.

(3) Relative to the three smelters, Lommel and Pelt are located along the direction of the prevailing winds, which originate from the south west $40 \%$ of the time and the north west $20 \%$ of the time.

(4) Arsenic may have been dispersed into the environment from secondary sources. The use of waste from plants producing zinc to build roads and heighten terrains in the past may explain the moderately increased urinary excretion of arsenic even in areas which are more remote from the smelters. Many of these roads have been covered during recent years.

(5) The increased urinary arsenic excretion in people living near non-ferrous metal plants are also in keeping with a previous study that showed that the arsenic absorption by school age children living around a lead smelter (situated near Antwerp) was higher than in their counterparts residing in a rural or urban control area. Contamination of the hands and possibly inhaled air were found to contribute to exposure. ${ }^{26} \mathrm{Hand}$ to mouth activity has also been identified as a primary source of arsenic absorption in children from a community surrounding a copper smelter in the United States. ${ }^{27}$ It is possible that this mode of transfer (direct ingestion of arsenic contaminated dust) also played a part in contamination of adults particularly in middle aged men who in rural areas are often engaged in physically demanding labour in the open air, such as gardening and agriculture.

(6) From baseline (1985-9) to follow up (1991-5), the urinary excretion of arsenic in Lommel and Pelt dropped almost fivefold. These changes coincided with major improvements in the local industrial processes. Indeed, before 1991 the zinc ore concentrates (containing about $80 \mathrm{mg} \mathrm{As} / \mathrm{kg}$ ) at the main zinc smelter in Wezel, located upwind from Lommel and Pelt, were stored and transported in open air, whereas later these activities were confined to closed hangars. In 1992, the primary zinc smelter in Pelt stopped its activity and only recycling of zinc products continued (Waeterschoot H, Union Minière, Brussels, personal communication, 1995). Also other industries, which potentially released inorganic arsenic into the environment, such as light bulb and glass manufacturing plants in Lommel, had to comply with the tighter environmental regulations imposed in 1991.

The people living in Lommel and Pelt were also informed around 1985 on how to reduce their environmental exposure to cadmium by not consuming well water, by liming the soil of their kitchen gardens and by not growing leafy vegetables. However, the promotion of these preventive measures was not coordinated across communities and was also not sustained over time. Unlike cadmium, liming the soil makes arsenic more mobile and available for 
uptake by vegetables. ${ }^{28}$ These temporary measures are therefore unlikely to have substantially contributed to the decrease in the arsenic exposure.

Another possible source of exposure to arsenic is through drinking water. According to local water companies, tap water distributed in the Noorderkempen and in Hechtel-Eksel is pumped from geological layers containing glauconite (iron arsenate) responsible for the water contamination by arsenic (Denteneer A, Departement of the Environment and Infrastructure, Ministry of the Flemish Community, Brussels, Belgium, personal communication, 1994). In Wezel inorganic arsenic had already been removed from the tap water before 1985, so that during the CadmiBel as well as during the PheeCad studies the arsenic content of the water was very low, probably $13 \mathrm{nmol} / /(1 \mu \mathrm{g} / \mathrm{l})$ or less (Maes J, PIDPA, Antwerp, Belgium, personal communication, 1995). In Hechtel-Eksel, Lommel, and Pelt the arsenic content of the drinking water was only reduced at a later stage. As a consequence, from 1985 to 1989 , the arsenic concentration in pipe water had varied from 520 to $707 \mathrm{nmol} / 1$ (39 to $53 \mu \mathrm{g} / \mathrm{l}$ ) in Lommel and from 107 to $307 \mathrm{nmol} / \mathrm{l}$ (8 to $23 \mu \mathrm{g} / \mathrm{l}$ ) in Pelt. From 1991 onwards, these ranges embraced 13 and $67 \mathrm{nmol} / \mathrm{l}(1$ and $5 \mu \mathrm{g} / \mathrm{l})$ and 27 and $53 \mathrm{nmol} / 1$ ( 2 and $4 \mu \mathrm{g} / \mathrm{l})$, respectively (Denteneer A, personal communication, 1994). In spite of these regional and temporal differences in the arsenic content of drinking water, the higher urinary excretion of arsenic in subjects living in the Noorderkempen region before 1990 cannot possibly be explained by the consumption of tap water alone. Indeed, Pelt and Hechtel-Eksel were supplied from the same wells and the drinking water was mixed before it was distributed (Keustermans L, Flemish Water Distribution Company, Hasselt, Belgium, personal communication, 1995). Yet, the urinary arsenic excretion was significantly higher in Pelt (373 $\mathrm{nmol} / 24 \mathrm{~h}, 28 \mu \mathrm{g} / 24 \mathrm{~h}$ ) than in Hechtel-Eksel (144 nmol $/ 24 \mathrm{~h}, 11 \mu \mathrm{g} / 24 \mathrm{~h}$ ). These findings strongly suggest the presence of another environmental source of inorganic arsenic in Pelt. The differences in the arsenic content of the drinking water between Hechtel-Eksel and Wezel during the CadmiBel era (1985-9) were also insufficient to lead to a measurable contrast in the urinary arsenic output, whereas, after imposition of stricter environmental regulations in 1991 and the reduction of the industrial emissions, a difference did emerge between Hechtel-Eksel and Wezel (fig 2).

Water from private wells could also have been a possible source of arsenic exposure in the Noorderkempen. However, all houses included in the CadmiBel study were supplied with tap water. In the Noorderkempen area only 18 subjects lived in houses which also had a private well, whereas in Hechtel-Eksel this number was 102 . The geological layers containing glauconite surface locally in HechtelEksel (Ide G, Lisec Research Centre for Ecology and Forestry, Genk, Belgium, 1990) and could have constituted a natural source of arsenic both through well water and through dust particles. In the Noorderkempen area where the increased exposure was found, these layers are located at a depth of $100 \mathrm{~m}$ or more (De Smedt P, Flemish Water Distribution Company, Brussels, Belgium, personal communication, 1995).

Men seem to be more exposed than women to inorganic arsenic. Smoking habit was not related to the urinary arsenic excretion and can therefore not account for these sex differences. Other factors related to lifestyle, such as working in open air and dietary habits, ${ }^{29}$ or differential toxicokinetics ${ }^{1}$ of inorganic arsenic in men and women may underly these sex differences. These were however minor by comparison with the influence of environmental factors.

An official network monitoring the arsenic content in air and fall out dust was in operation in the rural areas during the CadmiBel and PheeCad studies. ${ }^{3031}$ Measuring stations were posted around the non-ferrous smelters and in the residential areas of Lommel, Pelt, and Hechtel-Eksel. Inorganic arsenic in airborne dust was measured daily. These daily measurements were then computerised to obtain for each year the arithmetic mean, the $98^{\text {th }}$ percentile, and the maximum. However the measurements of the arsenic concentration in airborne dust were incomplete, because they were not performed in Hechtel-Eksel and also not in Lommel and Pelt from 1991 to 1993. Moreover, only airborne particles with an aerodynamic diameter of $10 \mu \mathrm{m}$ or less were sampled. Larger particles can also be inhaled and ingested with sputum coughed up but their arsenic content was not monitored. Also, the measurements in fall out dust performed at the stations of Hechtel-Eksel, Wezel, Lommel, and Pelt did not include arsenic. ${ }^{32}$

From the data made available, it seems that in the early 1980s the admissible thresholds for airborne arsenic ${ }^{31}$ (annual mean 0.02 $\mu \mathrm{g} / \mathrm{m}^{3} ; P_{98} 0.08 \mu \mathrm{g} / \mathrm{m}^{3}$, and $P_{100} \quad 0.2 \mu \mathrm{g} / \mathrm{m}^{3}$ ) have been exceeded at regular intervals, confirming the hypothesis of industrial pollution. More importantly, the official monitoring network did not detect the increased exposure of the population in Lommel and Pelt between 1985 and 1989, either as a consequence of missing measurements or due to lack of representitiveness of the measurements. The detection limit of arsenic in airborne dust was reportedly about $0.13 \mathrm{nmol} / \mathrm{m}^{3}\left(0.01 \mu \mathrm{g} / \mathrm{m}^{3}\right) .^{33}$

The present findings highlight the necessity to validate measurements in the environment, for instance by directly estimating the internal exposure of the concerned populations. Such a recommendation would certainly apply to areas at risk of an increased exposure to toxic substances, be it from natural or industrial sources.

A prospective follow up study of the morbidity and mortality in the Noorderkempen could also be initiated to find whether the increased exposure to inorganic arsenic in the past has led to adverse health effects. Indeed on the basis of the risk assessment model for 
arsenic developed by the Environmental Protection Agency ${ }^{34}$ and the toxicokinetics of arsenic excretion after exposure through the oral or pulmonary route, one may hypothesise that the increased exposure in Noorderkempen during the 1980 s may have been associated with an increased cancer risk.

The population surveys have been supported by the International Lead Zinc Research Organisation (Research Triangle Park, North Carolina, USA), the Province of Limburg (Hasselt, Belgium), the municipalities Hechtel-Eksel and Lommel (Belgium), the National Fund for Medical Research, the Incentive Program "Health Hazards" (Science Policy Office, Prime Minister's Services), the Ministry of the Flemish Community (Department of Labour and Social Affairs), the Health and Safety Directorate of the Commission of the European Communities, Astra Pharmaceuticals, and BristolMeyers-Squibb (all in Brussels, Belgium).

1 TSDR Agency for Toxic Substances and Disease Registry. Toxicological profile for arsenic. Atlanta, GA: US DepartToxicological profile for arsenic. Atlanta, GA:

2 Kasper ML, Schoenfield L, Strom RL, et al. Hepatic angiosarcoma and bronchioloalveolar carcinoma induced angiosarcoma and bronchioloalveolar carcinom

3 Chen CJ, Wang CJ. Ecological correlation between arsenic level in well water and age-adjusted mortality from malignant neoplasms. Cancer Res 1990;50:5470-4.

4 Pershagen G. Lung cancer mortality among men living near an arsenic-emitting smelter. Am $\mathcal{F}$ Epidemiol 1985; 122:684-94.

5 Lauwerys R, Bernard A, Buchet JP, et al. Does environmental exposure to cadmium represent a health risk? Conclusions from the CadmiBel study. Acta Clin Belg 1991;46:219-25.

6 Buchet JP, Lauwerys R, Roels H. Comparison of several methods for the determination of arsenic compounds in
water and in urine. Int Arch Occup Environ Health 1980; w6:11-29.

7 Lauwerys R, Amery A, Bernard A, Bruaux P, Buchet JP, Claeys $F$, et al. Health effects of environmental exposure to cadmium: objective, design and organization of the CadmiBel study: a cross-sectional morbidity study carried out in Belgium from 1985 to 1989. Environ Health Perspect 1990;87:283-9.

8 Staessen J, Bulpitt CJ, Fagard R, Joossens JV, Lijnen P, Amery A. Salt intake and blood pressure in the genera population: a controlled intervention trial in two towns. $\mathscr{F}$ Hypertens 1988;6:965-73.

9 Staessen JA, Buchet JP, Lauwerys RR, Lijnen P, Roels $\mathrm{H}$, Fagard R on behalf of the Working Groups. Public implications of environmental exposure to cadmium and lead cations of environmental exposure to cadmium and lead:
an overview of epidemiological studies in Belgium. $f$ Cardiovasc Risk 1995; (in press).

10 Staessen JA, Birkenhäger W, Bulpitt CJ, et al. The relationship between blood pressure and sodium and potassium excretion during the day and at night. $\mathcal{F}$ Hypertens 1993 11:443-7.

11 Staessen JA, Fagard R, Amery A. Life style as a determinant of blood pressure in the general population. $A m \mathcal{F}$ Hypertens 1994;7:685-94

12 Office of Population Censuses and Surveys. Classification of occupations. London: OPCS, 1980.

13 Yamada $\mathrm{Y}$, Ishizaki $\mathrm{M}$, Kido $\mathrm{T}$, et al. Alcohol, high blood pressure, and serum $\gamma$ glutamyltranspeptidase level. Hypertension 1991;18:819-26.

14 Buchet IP, Lauwerys R. Evaluation of exposure to inorganic arsenic in man. In: Facchetti S, ed. Analytical techganic arsenic in man. In: Facchetti S, ed. Analytical techniques for heavy metals

15 Buchet JP, Pauwels J, Lauwerys R. Assessment of exposure to inorganic arsenic following ingestion of marine organisms by volunteers. Environ Res $1994 ; 66: 44-51$.

16 Bartels H, Böhmer M. Eine Mikromethode zur
Kreatininbestimmung. Clin Chim Acta 1975;62:333-9.

17 Persyn JP, van der Silk W. A new method for the determination of gammaglutamyl transferase in serum. $f$ Clin Chem Clin Biochem 1976;14:421- 7.

18 Buchet JP, Lauwerys R, Roels $H$. Urinary excretion of inorganic arsenic and its metabolites after repeated ingestion of sodium metaarsenite by volunteers. Arch Occup Environ Health 1981;48:111-8.

19 Buchet JP, Lauwerys R, Roels H. Comparison of the urinary excretion of arsenic metabolites after a single dose of sodium arsenite, monomethylarsonate or dimethylarsinate in man. Int Arch Occup Environ Health 1981;48: $71-9$.

20 Offergelt JA, Roels H, Buchet JP, Boeckx M, Lauwerys R Relation between airborne arsenic trioxide and urinary Relation between airborne arsenic trioxide and urinary lites. Br F Ind Med 1992;49:387-98.

21 Buchet JP, Lauwerys R, Vandevoorde A, Pycke JM. Oral daily intake of cadmium, lead, manganese, copper, chromium, mercury, calcium, zinc, and arsenic in Belgium: a duplicate meal study. Food and Chemical Toxicology 1983;21:19-24.

22 Werkgroup Zware Metalen in de Kempen. Inventariserend onderzoek inzake de verontreiniging met zware metalen in de Kempen. Genk, Belgium: LISEC Studiecentrum voor Ecologie en Bosbouw, 1985. (In Dutch.)

23 Vangronsveld J, Van Assche F, Clijsters H. Reclamation of a base industrial area contaminated by non-ferrous metal: in situ metal immobilization and revegetation. Environ Pollution 1995;87:51-9.

24 Vanoronsveld J, Cammaer C, Van Assche F, Cliisters $H$ Reclamation of a "desert like" site in the north east of Belgium: evolution of the metal pollution and experiments in situ. In: Farmer JG, ed. 8th International Conference on Heavy Metals in the Environment. Edinburgh: CEP Consultants, 1991:58-61.

25 Vangronsveld J, Carleer R, Clijsters H. Transfer of metals and metalloids from soil to man through vegetables cultivated in polluted gardens: risk assessment and methods for immobilization of these elements in soils. In Varnavas SP, ed. 6th Int Conference on Environmental Contamination. Edinburgh UK, CEP Consultants. 1994: $142-5$.

26 Buchet JP, Roels H, Lauwerys R, et al. Repeated surveillance of exposure to cadmium, manganese, and arsenic in school-age children living in rural, urban, and nonferrous smelter areas in Belgium. Environ Res 1980;22: 95-108.

27 Plissar L, Lowry-Coble K, Kalman DA, Hughes JP, van Belle G, Covert DS, et al. Pathways of human exposure to arsenic in a community surrounding a copper smelter. Environ Res 1990;53:29-47.

28 Campbell JA, Stark JH, Carlton-Smith $\mathrm{CH}$. Effects of arsenic in sludge applied to soil. In: Lekkas TD, ed. 5th International Conference on Heavy Metals in the Environment. Edinburgh: CEP Consultants, 1985;1: 478-80.

29 Buchet JP, Lauwerys R. Fish consumption and exposure to arsenic. State of the art. Arch Public Health 1994;52: 171-4. (In French.)

30 Instituut voor Hygiene en Epidemiologie Stations Zware Metalen. Evaluatie van de gehalten aan zware metalen in de omgevingslucht in Belgie. faarrapport. Ministerie van de omgevingslucht in Belgie. Faarrapport. Ministerie
Volksgezondheid en Leefmilieu. Brussel: IHE, 1992.

31 Arseengehalte in de Noorderkempen. Erembodegem Belgium: Vlaamse Milieumaatschappij, 1994. (In Dutch.)

$32 \mathrm{De}$ neerslagkruiken in Vlaanderen. Overzichtsrappor 01/04/1986-31/03/1992. Erembodegem, Belgium: Bestuur Meetnetten en Onderzoek, Dienst Milieurapportering, Vlaamse Milieumaatscappij, 1994. (In Dutch.)

33 Evaluatie van de gehalten aan zware metalen in de omgevingslucht in Vlaanderen. Dertiende faarrapport 01/04/1992-31/03/1993. Erembodegem, Belgium: Bestuur Meetnetten en Onderzoek, Dienst Milieurapportering, Vlaamse Milieumaatschappij, 1994. (In porterin

34 Health assessment document for inorganic arsenic. Final report. Research Triangle Park, North Carolina: US Environmental Protection Agency, 1984.(EPA-600/8- 83-021F.) 